Creative commons User License: CC BY-NC-ND

Abstracted by: EBSCOhost, Electronic Journals Service (EJS),

Google Scholar, Journal Seek, Scientific Commons,

Food and Agricultural Organization (FAO), CABI and Scopus
Journal of Agricultural Extension

Vol. 22 (3) October, 2018

ISSN(e): 24086851; ISSN(Print); 1119944X

http://journal.aesonnigeria.org

http://www.ajol.info/index.php/jae

Email: editorinchief@aesonnigeria.org

\title{
Sustainable Land Management Practices Used by Farm Households for Climate Change Adaptation in South East Nigeria
}

https://dx.doi.org/10.4314/jae.v22i3.18

\section{Chukwuone, Nnaemeka A.}

Center for Entrepreneurship and Development Research and Department of Agricultural Economics, University of Nigeria, Nsukka

E-mail: nnaemeka.chukwuone@unn.edu.ng

\section{Chukwuone, Chiamaka}

Department of Home Economics and Hospitality Management, University of Nigeria, Nsukka, Email: chiamaka.chukwuone@unn.edu.ng

Phone: +234 8038750179

\section{Amaechina, Ebele C}

Department of Agricultural Economics, University of Nigeria, Nsukka

Email: ebele.amaechina@unn.edu.ng - Corresponding Author Phone: +234 8035010306

\section{Abstract}

The study determined the sustainable land management (SLM) practices used by farm households for climate change adaptation in South East Nigeria. Four hundred farm households selected through a multistage random sampling procedure from Enugu and Ebonyi States of Southeast Nigeria were interviewed for the study. Probit model was employed in estimating the determinants of SLM. Findings revealed that the predominant SLM practice is mulching/surface cover and the likelihood of use of mulching significantly increases with number of years the household head spent in school by 6 percent, and increased access to climate change information increased use by 27 percent. The study recommends that the government and civil society should provide information on climate change to the farm households through extension agents, enhance farm household's knowledge on climate change and provide incentives to enhance their income to facilitate the use of SLM by farm households in climate change adaptation.

Keywords: Sustainable land management, climate change, Adaptation, Farm households

\section{Introduction}

Climate change contributes to land and other natural resource degradation. Besides exposing soils to extreme and unfavourable conditions, climate change reduces the ability of some land management practices to achieve desired results (Malo, Jember and Woodfine, 2012). Land use is generally marked by a coinciding set of interests dictated by 
Creative commons User License: CC BY-NC-ND

Abstracted by: EBSCOhost, Electronic Journals Service (EJS),

Google Scholar, Journal Seek, Scientific Commons,

Food and Agricultural Organization (FAO), CABI and Scopus
Journal of Agricultural Extension

Vol. 22 (3) October, 2018

ISSN(e): 24086851; ISSN(Print); 1119944X

http://journal.aesonnigeria.org

http://www.ajol.info/index.php/jae

Email: editorinchief@aesonnigeria.org

agriculture, forestry, settlement, infrastructure and industry; however, "climate change affects these interests by influencing soil fertility, water resources and biomass accumulation through changing and more extreme weather patterns" (Streck, 2010). This results in vegetation cover degradation and loss of biodiversity, organic matter depletion, poor infiltration of rainwater and reduced capacity of soils to hold water and hence productivity losses (Food and Agricultural Organization (FAO), 2014). In fact, annual cropland productivity losses in Sub-Saharan Africa are between 0.5-1 percent suggesting $20 \%$ productivity loss over the last 40 years (World Meteorological Organization (WMO), 2005).

In Nigeria, it is projected that increased rainfall intensity, brought about by climate change, could lead to land degradation especially through flooding, erosion of farmlands, and a decrease in soil fertility (Federal Government of Nigeria (FGN), 2011). Rural Linkage Network, (2011) found that $89.0 \%$, of farmers in Niger Delta Nigeria, experienced heavy rainfall pattern and this could subsequently lead to land degradation and reduced output. In fact, rain negatively affected cassava output between the years 1980 and 2011 in Abia State Southeast Nigeria (Nwaobiala and Nottidge, 2013). Also, catastrophic flooding in Nigeria in 2012 led to the degradation of farmlands and crop loss amounting to 305.1 billion naira (FGN, 2013).

To reduce land degradation especially due to climate change and avert a subsequent decline in crop yield, there is a need to strengthen the use of responsible agricultural management, for example, sustainable land management practices (SLM). SLM refers to "knowledge-based procedure that helps integrate land, water, biodiversity, and environmental management to meet rising food and fibre demands while sustaining ecosystem services and livelihoods" (World Bank, 2006). SLM practices involve conservation agriculture, soil and water conservation, integrated ecosystem management practices and natural resources management (Motavalli, Nelson, Udawatta, Jose and Bardhun, 2013). These strategies have often been used for climate change adaptation. For example, most farmers in Ethiopia consider soil and water conservation techniques a key strategy in climate change adaptation (Deressa, Hassen, Alemu, Yesuf and Ringler, 2008). Many SLM technologies, for example, improved agronomic practices, nutrient management, irrigation, among others will help facilitate climate change adaptation, increase average productivity, and reduce the variability of production (TerrAfrica, 2009). Therefore, to strengthen the use of SLM practices in adaptation to climate change effects, especially through policy initiatives, there is a need to find out the determinants of the use of SLM in climate change adaptation by farm households especially in South East Nigeria, a part of the derived savannah zone where household's vulnerability to climate change is highest in Nigeria (Adewuyi, Folorunso, Okojie, and Akerele, 2014).

Although, previous studies have found some determinants of SLM practices, for example, Heyi and Mberengwa, (2012) found that education status, access to extension influenced the use of manure and terracing in Tole district in Ethiopia; Zeleke and Aberra (2014) 
Creative commons User License: CC BY-NC-ND

Abstracted by: EBSCOhost, Electronic Journals Service (EJS),

Google Scholar, Journal Seek, Scientific Commons,

Food and Agricultural Organization (FAO), CABI and Scopus
Journal of Agricultural Extension

Vol. 22 (3) October, 2018

ISSN(e): 24086851; ISSN(Print); 1119944X

http://journal.aesonnigeria.org

http://www.ajol.info/index.php/jae

Email: editorinchief@aesonnigeria.org

found that the most statistically significant determinants of adopting land management strategies in North-west Ethiopia were agro-ecological zone, family size,livestock ownership and access to climate information; Saguye (2017) found that age (younger age) number of livestock owned, extension contact, and perception of severity of land degradation influenced SLM practice in Jeldu district Ethiopia; the practices considered in this study are different. Besides, there is a need for more evidence, especially from Nigeria to enhance SLM policy initiatives considering that SLM is a complex issue and is influenced by different factors at a different scale (Heyi and Mberengwa, 2012). Jegede (2014) stressed the need to safeguard local people through "land sensitive" adaptation policies by governments in Africa. Hence the questions are: what SLM practices are used by farm households for climate change adaptation in South East Nigeria? What factors determine the use of SLM practices identified? The objectives of this paper are to identify the SLM practices used by farm households and to estimate the determinants of use of the major SLM practices identified in climate change adaptation.

\section{Methodology}

The study covered Enugu and Ebonyi States of Southeast Nigeria. The two states were randomly chosen from among five states in the zone (Enugu, Ebonyi, Anambra, Abia and Imo States). Ebonyi State, is situated between latitudes $7^{\circ} 30^{\prime} \mathrm{N}$ and $8^{\circ} 30^{\prime} \mathrm{N}$ and longitudes $5^{\circ} 40^{\prime} \mathrm{E}$ and $6^{\circ} 45^{\prime} \mathrm{E}$. Enugu State, lies between latitudes $5^{\circ} 56^{\prime} \mathrm{N}$ and $7^{\circ} 06^{\prime} \mathrm{N}$ and longitudes $6^{\circ} 53^{\prime} \mathrm{E}$ and $7^{\circ} 55^{\prime} \mathrm{E}$.

Selection of farm households used for the study was done through a multi-stage random sampling procedure. Ebonyi state has three agricultural zones while Enugu state has six. Two agricultural zones were selected in the first stage from the list of agricultural zones in the two States making four agricultural zones on the whole. The zones selected were Ebonyi Central and Ebonyi North from Ebonyi State and Enugu East and Enugu North zones from Enugu State. Secondly, two local government areas (LGA) were selected from each agricultural zone randomly giving eight LGAs, four for each state. The LGAs and number of communities (in parenthesis) are Afikpo North (10), Afikpo South (11), Ishielu (15), and Ezza South (10) for Ebonyi State; and Enugu East (33), Enugu South (18), Nsukka (18) and Uzouwani (16) LGA for Enugu State. In the third stage, five farming communities were selected from each of the eight LGAs, giving a total of 40 farming communities. Finally, 10 farm households were selected randomly from the list of households in each of the sampled communities. This gave a total of 400 farm households for the study. Extension agents assisted in interviewing the selected households.

Tools of participatory research, namely rapid rural appraisal, key informant interviews and semi-structured questionnaire were employed in data collection. A rapid rural appraisal involving key informants was conducted in some of the communities selected for the study to gather relevant information for the design of the questionnaire. The actual field survey was preceded by a pilot study to test the instrument. This was done in two communities that were not among those randomly selected for the study. From each of the two communities, fifteen farmers were interviewed, and the information received was further 
Creative commons User License: CC BY-NC-ND

Abstracted by: EBSCOhost, Electronic Journals Service (EJS),

Google Scholar, Journal Seek, Scientific Commons,

Food and Agricultural Organization (FAO), CABI and Scopus
Journal of Agricultural Extension

Vol. 22 (3) October, 2018

ISSN(e): 24086851; ISSN(Print); 1119944X

http://journal.aesonnigeria.org

http://www.ajol.info/index.php/jae

Email: editorinchief@aesonnigeria.org

used to finalize the questionnaire. The semi-structured questionnaire was thereafter used in collecting data on farm household's socio-economic attributes, sustainable land management practices used for adaptation to climate change by farmers, and returns and cost of farming. The household head or representative was interviewed. The respondents were asked to indicate the socioeconomic attributes of their household, for example, age in years, number of years spent in school, among others. Their knowledge of climate change, access to climate change information and information sources were also found out. On measurement of the variables, the age of household head and number of years spent in schools were measured in years while the household size was measured by number of members of the household.

To determine their knowledge of climate change, the farmers were asked to indicate whether they have heard of climate change, the extent they know about climate change and to describe the phenomenon to a friend. The respondents, in addition, indicated the SLM practices they have applied in climate change adaptation by saying yes or no to a particular practice. Yes, was assigned the value of one while no was zero for the regression model. They equally indicated the year they started practicing the measure and the type of climate change it was applied whether rainfall change or temperature change. The detail of how the variables used were measured is as shown in table 1 while Table 2 shows the means and standard deviations of explanatory variables used in the model.

\begin{tabular}{|c|c|}
\hline Variable & Description \\
\hline \multicolumn{2}{|l|}{ Household characteristics } \\
\hline Age of household head & In number of years \\
\hline Number of years in school of household head & Number of years spent in school \\
\hline Household size & Household size of members of the household \\
\hline Gender of household head - Males & Dummy takes the value of 1 if male and 0 otherwise \\
\hline Marital status & Dummy takes the value of 1 if married and 0 otherwise \\
\hline Access to climate change information & $\begin{array}{l}\text { Dummy takes the value of } 1 \text { if household head has access to } \\
\text { climate change information, } 0 \text { otherwise }\end{array}$ \\
\hline Sources of information on climate change & $\begin{array}{l}\text { Dummy takes the value of } 1 \text { if extension is the main source of } \\
\text { information on climate change, } 0 \text { otherwise }\end{array}$ \\
\hline Knowledge of climate change & 1 if household head knows about climate change, 0 otherwise \\
\hline Use of an SLM Practise & 1 if household indicated yes for the practice, 0 otherwise \\
\hline
\end{tabular}

Source: Description by the authors

Table 2: Description, variable means and standard deviation

\begin{tabular}{|c|c|c|c|c|}
\hline Variable & Mean & Standard Deviation & Minimum & Maximum \\
\hline \multicolumn{5}{|l|}{ Household characteristics } \\
\hline Age of household head & 51.68 & 14.37 & 14 & 98 \\
\hline $\begin{array}{l}\text { Number of years in school of household } \\
\text { head }\end{array}$ & 8.87 & 5.37 & 0 & 24 \\
\hline Household Size & 7.12 & 3.40 & 1 & 28 \\
\hline Gender of household head - Malesb & 0.84 & 0.37 & 0 & 1 \\
\hline Marital status & 0.80 & 0.40 & 0 & 1 \\
\hline Access to climate change information & 0.57 & 0.50 & 0 & 1 \\
\hline
\end{tabular}


Creative commons User License: CC BY-NC-ND

Abstracted by: EBSCOhost, Electronic Journals Service (EJS),

Google Scholar, Journal Seek, Scientific Commons,

Food and Agricultural Organization (FAO), CABI and Scopus
Journal of Agricultural Extension

Vol. 22 (3) October, 2018

ISSN(e): 24086851; ISSN(Print); 1119944X

http://journal.aesonnigeria.org

http://www.ajol.info/index.php/jae

Email: editorinchief@aesonnigeria.org

\begin{tabular}{lllll} 
Sources of information on climate change & 0.33 & 0.47 & 0 & 1 \\
Knowledge of climate change & 0.90 & 0.30 & 0 & 1 \\
\hline
\end{tabular}

Source: Field survey data 2012

The result in Table 2 shows that 52 years was the average age of the respondents. Average number of years spent in school is nine, while average household size is seven. In addition, more than $80 \%$ of the sampled household heads were males.

As regards data analysis, descriptive statistics especially percentages were used in determining some SLM used by farmers against climate change. In estimating the factors that determine the SLM adaptation strategy, we considered four practices applied by over $50 \%$ of the farmers. These practices are mulching/surface cover, fallowing, intercropping and farmyard manure. The estimation was done to determine the factors that influence the practising of each of the four strategies by farmers considering the fact noted by (Bryan et al., 2013) that factors that influence practices used may differ depending on the practice. Probit model was applied to estimate the determinants of use of each of the four SLM practices by the farm households for climate change adaptation. In the estimation, the dependent variable $y_{i}$ (SLM practice) takes the value 1 if the farm household uses a particular SLM practice, for example, mulching/surface cover; or 0 otherwise. Although $y_{i}$ is observable, the likelihood that a farm household will use SLM is unobservable and is given as a latent variable $y_{i}^{*}$ determined by a set of explanatory variables, which forms part of the vector $x^{t}$. The model is thus:

$y_{i}^{*}=x_{i}^{\prime} \beta+u_{i}----------------------------$ (1)-

$y_{i=1}$ if $y_{i}^{*}>0 ; y_{i}=0$ if $y_{i}^{*} \leq 0-------------------$ (2)

where the $i$ subscript represents respondents; the $\beta$ vector are the model parameters and $u$ is the error term which is normal distributed with a zero (0) mean and variance equal to one (1).

The model for estimating the determinants of SLM practices is specified as follows: $S L M_{i}=\beta_{1}+\beta_{2}$ age $_{i}+\beta_{3}$ No of years in school $_{i}+\beta_{4}$ gender $_{i}+\beta_{5}$ household size $_{i}$

$+\beta_{6}$ access to cc information ${ }_{i}$

$+\beta_{7}$ Extension agent as information soutrce ${ }_{i}+\beta_{8}{\text { knowldge of } c c_{i}}$

$+\beta_{10}$ Occupation $_{i}----------------(3)$

Maximum-likelihood estimation of the probit models was carried out. The marginal effects were also calculated from the different coefficients estimated in the models. The interpretation of these marginal effects is similar to that obtained in the linear regression models where the coefficients represent the change in the probability of use of a land management practice when a variable $X_{j}$ belonging to the vector. of exogenous variables $x^{\prime}$ changes by a unit, maintaining the other factors fixed, given that $\mathrm{E}\left(\mathrm{y}^{*} \mid x^{\prime}\right)=x^{\prime}$.

Tested for multicollinearity of the independent variables was carried out by checking the variance inflation factor (VIF) which showed non-existence of multicollinearity as the VIF of each of the variables was less than five (5). Green, 2008 noted that a variable is taken as being collinear if VIF exceeds 10 . 
Creative commons User License: CC BY-NC-ND

Abstracted by: EBSCOhost, Electronic Journals Service (EJS),

Google Scholar, Journal Seek, Scientific Commons,

Food and Agricultural Organization (FAO), CABI and Scopus
Journal of Agricultural Extension

Vol. 22 (3) October, 2018

ISSN(e): 24086851; ISSN(Print); 1119944X

http://journal.aesonnigeria.org

http://www.ajol.info/index.php/jae

Email: editorinchief@aesonnigeria.org

\section{Results and Discussion}

Thirty-eight percent (38\%) of the farmers used sustainable land management practices for adapting to climate change effects. Among the $38 \%$ of farmers that indicated that they practised some land management system, the details of SLM practices taken by the farmers is shown in Table 3. The result shows that the majority $(70.79 \%, 60.75 \%, 55.75 \%$ ad $52.00 \%$ ) of the farmers mulch/use surface cover, keep their land under fallow, intercrop and use farmyard manure respectively in adaptation to climate change effects.

Table 3: Sustainable land management practices used by farm households in climate change adaptation

\begin{tabular}{|c|c|c|c|}
\hline \multirow{2}{*}{$\begin{array}{l}\text { Sustainable land management } \\
\text { practices }\end{array}$} & \multirow{2}{*}{$\begin{array}{l}\% \text { of farmers } \\
\text { using the practice }\end{array}$} & \multicolumn{2}{|c|}{ Type of Climate Change } \\
\hline & & Rainfall Change & $\begin{array}{l}\text { Temperature } \\
\text { Change }\end{array}$ \\
\hline Mulching/surface cover & 70.79 & 56.75 & 63.25 \\
\hline Fallowing & 60.75 & 28.81 & 79.92 \\
\hline Intercropping & 55.75 & 72.60 & 28.25 \\
\hline Farmyard manure & 52.00 & 70.30 & 37.40 \\
\hline Crop rotation & 48.25 & 75.75 & 31.61 \\
\hline Increased Fertilizer & 47.50 & 23.68 & 41.05 \\
\hline Cover crops & 43.25 & 36.42 & 68.21 \\
\hline Erosion control & 39.75 & 74.84 & 3.77 \\
\hline Composting & 30.00 & 77.50 & 25.50 \\
\hline Removal of unwanted bush & 29.50 & 53.39 & 20.34 \\
\hline Agroforestry & 29.50 & 23.73 & 39.83 \\
\hline $\begin{array}{l}\text { Crop rotation with legumes } \\
\text { (nitrogen fixing) }\end{array}$ & 27.75 & 59.82 & 46.85 \\
\hline Soil improvement & 21.75 & 67.82 & 32.18 \\
\hline Replenishing soil fertilizer & 16.50 & 66.67 & 24.24 \\
\hline Border cropping & 6.75 & 51.85 & 14.81 \\
\hline Water harvesting & 6.00 & 45.83 & 45.83 \\
\hline Land enclosure & 5.75 & 60.87 & 0.00 \\
\hline Trash line & 1.50 & 100.00 & 0.00 \\
\hline Infiltration ditches & 1.50 & 100.00 & 0.00 \\
\hline
\end{tabular}

Source: Field survey data 2012, Multiple responses was recorded in type of climate change observed

The opinion of farmers regarding the type of climate change effect addressed by the SLM practices is also shown in Table 3. Although some did not indicate the particular climate 
Creative commons User License: CC BY-NC-ND

Abstracted by: EBSCOhost, Electronic Journals Service (EJS),

Google Scholar, Journal Seek, Scientific Commons,

Food and Agricultural Organization (FAO), CABI and Scopus
Journal of Agricultural Extension

Vol. 22 (3) October, 2018

ISSN(e): 24086851; ISSN(Print); $1119944 X$

http://journal.aesonnigeria.org

http://www.ajol.info/index.php/jae

Email: editorinchief@aesonnigeria.org

change effect the SLM was applied, the result as regards the SLM practiced by the majority of the farm households shows that $63.25 \%$ and $79.92 \%$ of the farm households used mulching and fallowing respectively in adapting to temperature effects. On the other hand, $72.60 \%$ and $70.30 \%$ of the farm households used intercropping and farmyard manure respectively in adapting to rainfall effects. Intercropping, for example, can help to reduce run-off and thus soil erosion. Himanen, Makinen, Rimhanen and Savikko (2016) found out that intercropping can help in the regulation of water dynamics in addition to enhancing soil nutrient.

The parameter estimates and marginal effects of the determinants of some sustainable land management practices for climate change adaptation by farm households is presented in Table 4. The SLM practices considered are mulching/use surface cover, keeping their land under fallow, intercropping and use of farmyard manure.

Table 4: Determinants of use of sustainable land management practices for climate change adaptation by farm households

\begin{tabular}{|c|c|c|c|c|c|c|c|c|}
\hline \multirow[t]{2}{*}{ Explanatory Variable } & \multicolumn{4}{|l|}{ Coefficients } & \multicolumn{4}{|c|}{ Marginal Effects } \\
\hline & $\begin{array}{l}\text { Mulching/su } \\
\text { rface cover }\end{array}$ & $\begin{array}{l}\text { Farmyard } \\
\text { manure }\end{array}$ & Fallowing & $\begin{array}{l}\text { Interc } \\
\text { roppi } \\
\text { ng }\end{array}$ & $\begin{array}{l}\text { Mulching/sur } \\
\text { face cover }\end{array}$ & $\begin{array}{l}\text { Farmyard } \\
\text { manure }\end{array}$ & Fallowing & $\begin{array}{l}\text { Inter } \\
\text { cropping }\end{array}$ \\
\hline Household head age & $\begin{array}{l}0.013^{\star \star} \\
(0.006)\end{array}$ & $\begin{array}{l}0.013^{\star *} \\
(0.007)\end{array}$ & $\begin{array}{l}0.015^{\star \star} \\
(0.006)\end{array}$ & $\begin{array}{l}0.017^{\star \star \star} \\
(0.007)\end{array}$ & $\begin{array}{l}0.004^{\star \star} \\
(0.002)\end{array}$ & $\begin{array}{l}0.004^{\star \star} \\
(0.002)\end{array}$ & $\begin{array}{l}0.005^{\star \star} \\
(0.002)\end{array}$ & $\begin{array}{l}0.005^{\star \star \star} \\
(0.002)\end{array}$ \\
\hline $\begin{array}{l}\text { Number of years spent in } \\
\text { school by household head }\end{array}$ & $\begin{array}{l}0.069^{* * *} \\
(0.014)\end{array}$ & $\begin{array}{l}0.072^{\star \star \star} \\
(0.016)\end{array}$ & $\begin{array}{l}0.077^{\star * *} \\
(0.015)\end{array}$ & $\begin{array}{l}0.084^{* \star *} \\
(0.016)\end{array}$ & $\begin{array}{l}0.024^{* * *} \\
(0.005)\end{array}$ & $\begin{array}{l}0.020^{\star * *} \\
(0.004)\end{array}$ & $\begin{array}{l}0.025^{\star * \star} \\
(0.005)\end{array}$ & $\begin{array}{l}0.026^{\star * \star} \\
(0.005)\end{array}$ \\
\hline Household Size & $\begin{array}{l}0.003 \\
(0.222)\end{array}$ & $\begin{array}{l}0.013 \\
(0.024)\end{array}$ & $\begin{array}{l}0.030 \\
(0.232)\end{array}$ & $\begin{array}{l}0.068^{\star \star \star} \\
(0.024)\end{array}$ & $\begin{array}{l}0.001 \\
(0.008)\end{array}$ & $\begin{array}{l}0.004 \\
(0.007)\end{array}$ & $\begin{array}{l}0.010 \\
(0.008)\end{array}$ & $\begin{array}{l}0.021^{\star \star \star} \\
(0.008)\end{array}$ \\
\hline $\begin{array}{l}\text { Gender of household head } \\
- \text { Males }^{\text {b }}\end{array}$ & $\begin{array}{l}-0.085 \\
(0.216)\end{array}$ & $\begin{array}{l}-0.122 \\
(0.237)\end{array}$ & $\begin{array}{l}-0.269 \\
(0.226)\end{array}$ & $\begin{array}{l}-0.310 \\
(0.234)\end{array}$ & $\begin{array}{l}-0.030 \\
(0.078)\end{array}$ & $\begin{array}{l}-0.035 \\
(0.071)\end{array}$ & $\begin{array}{l}-0.912 \\
(0.081)\end{array}$ & $\begin{array}{l}-0.103 \\
(0.082)\end{array}$ \\
\hline $\begin{array}{l}\text { Access to climate change } \\
\text { information }\end{array}$ & $\begin{array}{l}0.274^{*} \\
(0.163)\end{array}$ & $\begin{array}{l}0.493^{\star * \star} \\
(0.179)\end{array}$ & $\begin{array}{l}0.303^{*} \\
(0.173)\end{array}$ & $\begin{array}{l}0.389^{* *} \\
(0.177)\end{array}$ & $\begin{array}{l}0.095^{*} \\
(0.055)\end{array}$ & $\begin{array}{l}0.134^{\star * \star} \\
(0.046)\end{array}$ & $\begin{array}{l}0.096^{*} \\
(0.054)\end{array}$ & $\begin{array}{l}0.118^{\star \star} \\
(0.052)\end{array}$ \\
\hline $\begin{array}{l}\text { Extension agent as } \\
\text { information source }\end{array}$ & $\begin{array}{l}0.236 \\
(0.166)\end{array}$ & $\begin{array}{l}0.381^{* *} \\
(0.177)\end{array}$ & $\begin{array}{l}0.301^{*} \\
(0.171)\end{array}$ & $\begin{array}{l}0.156 \\
(0.17 \\
7) \\
\end{array}$ & $\begin{array}{l}0.084 \\
(0.059)\end{array}$ & $\begin{array}{l}0.112^{\star \star} \\
(0.054)\end{array}$ & $\begin{array}{l}0.100^{*} \\
(0.058)\end{array}$ & $\begin{array}{l}0.049 \\
(0.057)\end{array}$ \\
\hline $\begin{array}{l}\text { Improved planting } \\
\text { materials }\end{array}$ & $\begin{array}{l}0.014 \\
(0.153)\end{array}$ & $\begin{array}{l}0.142 \\
(0.169) \\
\end{array}$ & $\begin{array}{l}0.090 \\
(0.160)\end{array}$ & $\begin{array}{l}0.266 \\
(0.165) \\
\end{array}$ & $\begin{array}{l}0.004 \\
(0.053)\end{array}$ & $\begin{array}{l}0.039 \\
(0.046)\end{array}$ & $\begin{array}{l}0.029 \\
(0.051) \\
\end{array}$ & $\begin{array}{l}0.081^{*} \\
(0.049)\end{array}$ \\
\hline Agric production & $\begin{array}{l}-0.007 \\
(0.153)\end{array}$ & $\begin{array}{l}-0.138 \\
(0.166)\end{array}$ & $\begin{array}{l}0.144 \\
(0.163)\end{array}$ & $\begin{array}{l}0.163 \\
(0.168)\end{array}$ & $\begin{array}{l}-0.002 \\
0.053\end{array}$ & $\begin{array}{l}-0.039 \\
(0.046)\end{array}$ & $\begin{array}{l}0.046 \\
(0.052)\end{array}$ & $\begin{array}{l}0.051 \\
(0.052)\end{array}$ \\
\hline $\begin{array}{l}\text { Knowledge of climate } \\
\text { change }\end{array}$ & $\begin{array}{l}0.536^{*} \\
(0.303)\end{array}$ & $\begin{array}{l}-0.032 \\
(0.299)\end{array}$ & $\begin{array}{l}0.791^{* *} \\
(0.373)\end{array}$ & $\begin{array}{l}0.499 \\
(0.34 \\
0)\end{array}$ & $\begin{array}{l}0.162^{* *} \\
(0.076)\end{array}$ & $\begin{array}{l}-0.009 \\
(0.085)\end{array}$ & $\begin{array}{l}0.196^{\star * *} \\
(0.063)\end{array}$ & $\begin{array}{l}0.132^{\star} \\
(0.073)\end{array}$ \\
\hline Constant & $\begin{array}{l}-2.447^{\star * *} \\
(0.479) \\
\end{array}$ & $\begin{array}{l}-2.552^{* * *} \\
(0.508)\end{array}$ & $\begin{array}{l}-3.218^{\star * *} \\
(0.544) \\
\end{array}$ & $\begin{array}{l}-3.509^{* * \star} \\
(0.537) \\
\end{array}$ & & & & \\
\hline
\end{tabular}

Source: Computations from 2012 field survey

Note: ${ }^{* * *} \mathrm{P} \leq 0.01,{ }^{* *} \mathrm{P} \leq 0.05$, and ${ }^{*} \mathrm{P} \leq 0.10$ Values in parenthesis are standard errors. 
Creative commons User License: CC BY-NC-ND

Abstracted by: EBSCOhost, Electronic Journals Service (EJS),

Google Scholar, Journal Seek, Scientific Commons,

Food and Agricultural Organization (FAO), CABI and Scopus
Journal of Agricultural Extension

Vol. 22 (3) October, 2018

ISSN(e): 24086851; ISSN(Print); 1119944X

http://journal.aesonnigeria.org

http://www.ajol.info/index.php/jae

Email: editorinchief@aesonnigeria.org

The result shows that the likelihood of using mulching/ surface cover, keeping land under fallow, intercropping and using farm yard manure significantly increases with age and number of years spent in school by the household head although with low but significant marginal effects. For education, this finding is expected as educated households may be more aware of the benefits of the practices and will be more efficient in their use. The finding as regards age is not in line with expectation as previous studies, for example, (Saguye, 2017) showed that younger people are more likely to use SLM practices. However, the reason could be that older people have better knowledge about the local practices and are more likely to use them than younger people. In addition, the likelihood of using farm yard manure, keeping land under fallow, and mulching significantly increases with an increase in access to climate change information by 13, 10 and 9 percentage point respectively.

This finding suggests that access to climate change information is very critical in the use of these practices in climate change adaptation. Also, extension agents being the source of information on climate change, significantly increases the likelihood of use of farmyard manure and fallowing as SLM practices in climate change adaptation by $11 \%$ and $10 \%$ respectively. This finding suggests using extension agents in delivering information on the use of farmyard manure and fallowing as SLM practices for climate change adaptation will enhance the practices. These findings are in line with that of Heyi and Mberengwa, (2012) that education status and access to extension influenced the use of manure in Tole district of Ethiopia. Furthermore, the result revealed that the likelihood of keeping land under fallow as an SLM strategy for climate change adaptation significantly increases with having knowledge about climate change by $19 \%$. Moreover, the result revealed that the likelihood of intercropping increases with household size.

\section{Conclusion and Recommendations}

The study showed that the likelihood of keeping land under fallow, mulching and use of farmyard manure in climate change adaptation significantly increases with the increase in access to climate change information, especially from agricultural extension agents. Knowledge about climate change also influenced the use of SLM in climate change adaptation by farm households especially keeping land under fallow and mulching.

Therefore, to encourage the use of SLM practices especially the use of mulching/ surface cover, keeping land under fallow, intercropping and use of farmyard manure by farm households for climate change adaptation, government should support the provision of climate change information through agricultural extension agents especially to farmers with some level of education and knowledge about climate change. Moreover, the government should also provide some production incentives to farmers, for example, improved planting materials, in order to encourage the use of SLM practices for climate change adaptation. 
Creative commons User License: CC BY-NC-ND

Abstracted by: EBSCOhost, Electronic Journals Service (EJS),

Google Scholar, Journal Seek, Scientific Commons,

Food and Agricultural Organization (FAO), CABI and Scopus
Journal of Agricultural Extension

Vol. 22 (1) February, 2018

ISSN(e): 24086851; ISSN(Print); 1119944X

http://journal.aesonnigeria.org

http://www.ajol.info/index.php/jae

Email: editorinchief@aesonnigeria.org

\section{References}

Adewuyi, S.A, Folorunso, L.O, Okojie, L.O and Akerele, D. (2014) Effect of climate change on food crop production and vulnerability assessments in Oyo State. Journal of Economics and International Finance, 7 (1)18-24.

Bryan, E., Ringler, C., Okoba, B., Roncoli, C., Silvestri, S., \&Herrero, M. (2013) Adapting agriculture to climate change in Kenya: Household strategies and determinants. Journal of Environmental Management, 114, 26-35.

Deressa, T., R. Hassen, T. Alemu, M. Yesuf, \& Ringler, C. (2008). Analyzing the determinants of farmers' choice of adaptation measures and perceptions of climate change in the NileBasin of Ethiopia, International Food Policy Research Institute (IFPRI) Discussion PaperNo. 00798, Washington, DC: IFPRI.

Food and Agricultural Organisation ( FAO). (2014) Adapting to climate change through land and water management in Eastern Africa: results of pilot projects in Ethiopia Kenya and Tanzania. Rome, FAO.

Federal Government of Nigeria (FGN), (2011) National Adaptation Strategy and Plan of Action on Climate Change for Nigeria (NASPA-CCN). Federal Ministry of Environment Climate Change Department, Abuja.

FGN, (2013) Nigeria Post Disaster Needs Assessment 2012 Flood. A Report by the Federal Government of Nigeria with Technical Support from the World Bank, EU, UN, and Other Partners. Abuja, FGN.

Green, W.H., (2008). Econometric Analysis, 6th ed. Upper SaddleRiver, NJ: PrenticeHall.

Jegede A.O. (2014) Climate Change: safeguarding indigenous peoples through "land sensitive" adaptation policy in Africa. In Walter Leal Filho(Ed.), Handbook of Climate Change Adaptation. Berlin, Springer. DOI- 101007/978-3-642-404559 2-1.

Heyi, D.D., and Mberngwa, I. (2012) Determinants of farmers' land management practices: the case of Tole District South West Shewa zone, Oromia National Regional State Ethiopia. Journal of Sustainable Development in Africa, 14(1)76-96.

Himanen, S.J., Makinem, H., Rimhanen, K., and Savikko, R (2016) Engaging farmers in climate change adaptation planning: Assessing intercropping as a means to support farm adaptive capacity. Agriculture, 6(34); doi:10.3390/agriculture6030034.

Malo, M., Jember, G. and Woodfine, A.C. (2010) Strengthening Capacity for Climate Change Adaptation in the Agriculture Sector in Ethiopia. Proceedings from National Workshop held in Nazreth, Ethiopia 5-6 July 2010. Climate,Energy and Tenure Division, Natural Resources Management and Environment Department, Food and Agriculture Organization of the United Nations, (Rome, Italy, 2012). Available from: http://www.fao.org/docrep/014/i2155e/i2155e00.pdf [Accessed Oct 2013] 
Creative commons User License: CC BY-NC-ND

Abstracted by: EBSCOhost, Electronic Journals Service (EJS),

Google Scholar, Journal Seek, Scientific Commons,

Food and Agricultural Organization (FAO), CABI and Scopus
Journal of Agricultural Extension

Vol. 22 (1) February, 2018

ISSN(e): 24086851; ISSN(Print); 1119944X

http://journal.aesonnigeria.org

http://www.ajol.info/index.php/jae

Email: editorinchief@aesonnigeria.org

Motavalli, P., Nelson, K., Udawatta, R., Jose, S.,and Bardhan, S. (2013) Global achievements in sustainable land management. International Soil and Water Conservation Research, 1(1),1-10.

Nwaobiala, C.U, and Nottidge, D.O. (2013) Effect of climatic variables on cassava farmers' production in Abia State Nigeria. Nigeria Journal of Agriculture, Food and Environment, 9(4): 57-62

Rural Linkage Network (2011). Assessment of impacts, vulnerability, adaptive capacity and adaptation to climate change in the Niger Delta Region, Nigeria. In Building Nigeria Response to Climate Change: Reports of Research Projects on Impacts and Adaptation - Climate Change in Nigeria. Ibadan, Nigeria Environmental Study Action Team (NEST).

Saguye, T.S (2017) Determinants of adoption of sustainable land management (SLM) practices among smallholder farmers' in Jeldu District, West Shewa Zone, Oromia Region, Ethiopia. Journal of Resources Development and Management, 30: 111-127.

Streck, C. (2010) How climate change can catalyze sustainable land-management. International Development Law Organization (IDLO) Sustainable Development Law on Climate Change Legal Working Paper Series No 15. Rome: IDLO.

TerraAfrica (2009) Land and Climate: The role of sustainable land management for climate change adaptation and mitigation in Sub-Saharan Africa. A TerraAfrica Partnership Publication.

World Bank (2006) Sustainable Land Management: Challenges, Opportunities and Trade-Offs. Washington, D.C: The International Bank for Reconstruction and Development/The World Bank.

World Metrological Organization (2005) Land and Climate Degradation. WMO No 989, Geneva, WMO.

Zeleke, M.T.,and Aberra, Y. (2014) Determinants of the adoption of land management strategies against climate change in North-west Ethiopia',ERJSSH (1).

\section{Acknowledgment}

The authors gratefully acknowledge the financial and technical support from African Growth and Development Policy Modelling Consortium (AGRODEP) and International Food Policy Research Institute (IFPRI). 